Vol. 12 (1) June, 2008

\title{
Effect of Group Participation on Access to Micro-Credit among Rural Women in Osun and Oyo States, Nigeria
}

\author{
Saka J. O ${ }^{a^{*}}$, B. O. Lawal ${ }^{a}$, Abeeb Waliyat ${ }^{b}$, O. L. Balogun ${ }^{c}$ and A. Oyegbami ${ }^{a}$ \\ ${ }^{a}$ Institute of Agricultural Research and Training, Ibadan \\ ${ }^{a}$ Federal College of Agriculture, Ibadan. \\ ${ }^{c}$ Department of Agricultural Economics, University of Ibadan \\ *Correspondence Author: saka sakang@yahoo.com
}

\begin{abstract}
Various reports have it that poverty is more prevalent among people in rural communities with women being the most vulnerable group. Globally, improved access to micro credit is promoted as an important strategy in the struggle against poverty in developing economies. Using a sample of 104 rural women selected through multi-stage sampling technique, this study examined group participation and access to micro credit among women in rural communities of Osun and Oyo States, Nigeria. The results showed that about $85.6 \%$ of rural women belonged to micro credit groups notably religious and traders associations through which $42.3 \%$ were able to source credit. Rural women were only able to meet $40.3 \%$ of the capital need through micro-credit offered by the groups. Cooperative societies granted higher volume of credit than the local groups while women farmers had access to greater volume of credit than women traders; however, micro credit was yet to have significant impact on poverty status of the women.
\end{abstract}

Keywords: micro-credit, rural women, poverty

\section{INTRODUCTION}

Over the past two decades there has been increased recognition of micro credit as one of the leading strategies in poverty eradication among nations of the world. In effect, the World Summit for Social Development, held in Copenhagen in March 1995, underlined the importance of improving access to credit for small rural or urban producers, landless farmers and other people with low or no income, with special attention to the needs of women and disadvantaged and vulnerable groups (UNO 1998).

Records have also revealed that more than one billion people across the world today live in poverty with Nigeria harbouring over 60 million of this number $(6 \%$ percent of the total figure) (Nwachukwu, 2006). As the most populous and one of the largest countries in sub-Sahara Africa, the issue of poverty in Nigeria is of concern not only in itself but also as a challenge for poverty reduction mandate in the entire African continent. Though, Nigeria is blessed with abundant physical and human resources, there had been progressively worsening welfare and poverty condition of its nationals (Okunmadewa, 2001). 
However, research reports and official documents show that poor people in Nigeria tend to be concentrated in communities that lack the benefits of modern development. Rural areas and urban fringes have a slightly higher concentration of poor people (Ayanwale and Alimi 2004).

Generally, available estimates (CIA 2008, DFID 2008) have shown that about $70 \%$ of the population leaves below poverty line while poverty reduction in the country has been rated to be very slow with decreasing potential for meeting the Millennium Development Goal (MDG) 2015 target. In addition, Nwachukwu et al (2007) asserted that evidence from previous surveys conducted by the Federal Office of Statistics showed that poverty in Nigeria is overwhelmingly a rural problem. Various reports (Ajetomobi 1995, World Bank 1999 quoted in Ayanwale and Alimi 2004, Ajao 2000, Ajani 2008, Kareem et al 2008) also have it that people in rural communities and especially women are the most vulnerable group in Nigeria owing to their limited access to productive resources, coping strategies, safety nets and constantly growing sense of insecurity.

This possibly explains the focusing of poverty alleviation programmes on rural communities by various administrations in Nigeria over the years as noted by Ogwumike (2002).

In recognition of micro credit as an important tool in the struggle against poverty, CBN (1999) reported the significance of credit and other inputs to agricultural output and submitted that the provision and use of these inputs in the right proportion were crucial to increasing agricultural output and productivity in Nigeria. Availability and proper usage of inputs/credit has also been empirically proved to enhance productivity level of farm households in Nigeria (Okoruwa and Oni, 2002). However, since it has also been established that women are usually at the receiving ends in accessing production incentives and it has even been suggested that such limitations could be removed through group participation. It then becomes pertinent to investigate the extent to which group participation has been able to enhance access to credit among women in rural communities in Osun and Oyo States, Nigeria.

\section{METHODOLOGY}

Data for this study were generated from a household survey of 120 women selected through a multi-stage sampling technique. The first stage involved purposive selection of two ADP zones that are predominantly rural in geographical distribution, followed by selection of ten villages from each of the zones. Rural households were randomly selected from the list of households members obtained from member of each of the villages who served as contact for the study.

However, a total of 104 questionnaires certified as containing adequate information relevant to the scope of the study were used in the analysis. Data generated were analyzed using descriptive statistics including frequency distribution, percentages, and means while chi-square statistic was used to draw inference about the dependence of group participation on poverty status of rural women. The study adopted two-third of mean household expenditure (Oke et al 2007) as the poverty line. 


\section{RESULTS AND DISCUSSION}

\section{Socio-economic Characteristics and Membership of micro-credit groups}

The distribution of the respondents on the basis of their socio-economic characteristics and the relationship between these and membership of micro-credit group among rural women is shown on Table 1 . The distribution of the women by their age group indicates that majority of the women were within the productive age of 20 to 60 years and belong to micro credit associations (85.6\%). There was no significant difference in the average age of women who were members of micro credit groups (44.1) and non members (42.8). The results also indicated that majority of the rural women $(62.5 \%)$ had formal education form primary schools $(20.2 \%)$; secondary school $(26.0 \%)$ and post secondary schools $(16.3 \%)$ while a greater percentage $(48 \%)$ were members of micro credit associations. The study has shown that majority of the women in micro credit group were within the productive age in addition to having formal education. This is in consonance with earlier findings (Ayanwale and Alimi 2004, Oke et al, 2007) that members of micro-credit groups were mostly within the productive age and had formal education

Meanwhile, trading in farm produce $(82.7 \%)$ was the commonest vocation among the respondents with about $68 \%$ of the women traders belonging to microcredit. This agrees with an earlier study (Oke et al 2007) that more female members of micro-credit groups were involved in non-farming businesses than farming businesses. In addition, about $52 \%$ had alternative sources of income alongside their primary vocation and were predominantly members of micro-credit groups $(44.2 \%)$. The distribution of the population by religious sect is indicative of the importance of Islam $(57.7 \%)$ and Christianity $(42.3 \%)$ among women in rural communities of the study area. However, a greater percentage of women under the two religions were members of micro-credit associations.

Further analysis of the distribution also suggested that age group, level of education; religion and type of family had significant relationship with membership of micro-credit associations among rural women. The dominance of the population by women within the productive age and the prevalence of literate majority are reflective of availability of physical and mental strength, and innovativeness for entrepreneurial initiatives among the rural women. The combined influence of these is thus capable of stimulating increased drive for investible fund and consequently, participation in micro credit groups. In addition, an educated population is known to provide the ingredient for adequate exposure to the basic skills required in organizing, coordinating and managing not only the acquired fund but also the home grown informal sources of such fund. The relevance of these had been demonstrated in earlier studies (Ayanwale and Alimi 2004) of micro credit groups with emphasis on the importance of age and level of education on managing of micro credit group and credit sourcing.

The impact of religion on credit according to Kessey (2005), takes root in moral basis regarding the prohibition of interest (riba) by Muslims and this could, to some extent constitute a limiting factor on sourcing of credit from formal institutions by this group. However, emerging trends in the roles played by religious groups and associations in the struggle against poverty through economic empowerment at the grassroots is a testimony to the potential influence that religion can play in membership and functioning of micro-credit groups. 
Similarly, the influence of family type (monogamous or polygamous) and its attendant influence on family size and pressure on family resources are capable of stimulating the drive from extra-household means of meeting competing ends. Consequent upon this, the drive for additional support outside personal earnings might be more pronounced within one family type and the other especially as this study has shown that members of micro-credit group have smaller family size and number of children in the household than non members. Perhaps, smaller family size affords opportunity for savings, which is a significant feature of membership of micro-credit groups. 
Journal of Agricultural Extension

Vol. 12 (1) June, 2008

TABLE 1: Influence of socio-economic characteristics of Respondents on Group Participation among rural women

\begin{tabular}{|c|c|c|c|}
\hline Characteristics & Member & Non Member & $\begin{array}{c}\text { Test Statistic } \\
\text { Value }\end{array}$ \\
\hline \multicolumn{4}{|l|}{ Age Group (Years) } \\
\hline $21-40$ & $26(25.0)$ & $10(9.6)$ & $7.956^{\mathrm{C} *}$ \\
\hline $41-60$ & $63(60.6)$ & $05(4.8)$ & \\
\hline \multicolumn{3}{|l|}{ Level of Education } & $0.605^{t}$ \\
\hline None & $39(37.5)$ & $0(0.0)$ & $49.988^{C} *$ \\
\hline Primary School & $21(20.2)$ & $0(0.0)$ & \\
\hline Secondary School & $12(11.5)$ & $15(14.4)$ & \\
\hline Post Secondary & $17(16.3)$ & $0(0.0)$ & \\
\hline \multicolumn{4}{|l|}{ Occupation } \\
\hline Farming & $05(4.8)$ & $0(0.0)$ & $3.669^{C}$ \\
\hline Trading in farm produce & $71(68.3)$ & $15(4.4)$ & \\
\hline Trading in non-farm & $5(4.8)$ & $0(0.0)$ & \\
\hline products & $5(4.8)$ & $0(0.0)$ & \\
\hline Civil Servant & $03(2.9)$ & $0(0.0)$ & \\
\hline \multicolumn{4}{|l|}{ Agro-Processor } \\
\hline Alternative Income & $46(44.2)$ & $8(7.7)$ & $0.014^{C}$ \\
\hline Source & $43(41.3)$ & $7(6.7)$ & \\
\hline \multicolumn{4}{|l|}{ Yes } \\
\hline No & $60(57.7)$ & $0(0.0)$ & $23.902^{C *}$ \\
\hline \multicolumn{3}{|l|}{ Islam } & \\
\hline Christianity & $47(45.2)$ & $0(0.0)$ & $14.453^{C *}$ \\
\hline Type of Family & $42(40.4)$ & $15(4.4)$ & \\
\hline Monogamous & 7.4 & 9.7 & $3.667^{t *}$ \\
\hline Polygamous & 3.8 & 4.3 & $1.890^{t *}$ \\
\hline Household size (Mean) & & & \\
\hline Number of Children (mean) & & & \\
\hline
\end{tabular}

Source: Survey data 2007

* Significant $(P \leq 0.05) . t=T$ value $C=C h i$ Square Value

\section{Type of Associations and Sources of Micro Credit}

Table 2 shows the distribution of rural women by the type of credit associations joined and the major sources of micro-credit. The results showed that religious association and traders associations were the prominent form of micro-credit groups joined by $70.2 \%$ and $48.1 \%$ of the respondents respectively. However, credits were commonly sourced from local micro-credit groups and cooperative societies thereby underscoring the importance of local associations in financing micro-credit needs of rural women. In the same vein, the results had as envisaged earlier pinpointed the increasing importance of religious organizations in providing ground for women economic empowerment as about $70 \%$ of the respondents belonged to these associations. 
TABLE 2: Type of Associations and Sources of Credit

\begin{tabular}{|c|c|c|}
\hline Type of Association ${ }^{a}$ & Frequency & Percentage \\
\hline Cooperative Societies & 05 & 4.8 \\
\hline Traders Association & 50 & 48.1 \\
\hline Religious Association & 73 & 70.2 \\
\hline Farmers Association & 02 & 1.9 \\
\hline \multicolumn{3}{|l|}{ Sources of Credit } \\
\hline Cooperative societies & 02 & 1.9 \\
\hline Money lenders & 0 & \\
\hline Community Banks & 0 & 0 \\
\hline Commercial Banks & 0 & 0 \\
\hline Government Credit Agencies & 0 & 0 \\
\hline Local Micro-credit groups & 28 & 26.9 \\
\hline Friends and Relatives & 0 & 0 \\
\hline $\begin{array}{l}\text { Cooperatives and Local micro-credit } \\
\text { groups }\end{array}$ & 11 & 10.6 \\
\hline
\end{tabular}

Source: Survey data 2007

${ }^{a}$ Multiplicity of membership of associations

The study has shown that majority of the women belong to various form of micro-credit groups thereby underscoring the contribution of previous economic empowerment policies and programmes targeted at group participation for enhanced access to credit among rural women. However, the dominance of non formal groups over others like cooperative societies undermines the impact that the policies were designed as regards sourcing credit from formal sources. This is evident in the marked dependence on local groups for credit that is not known to guarantee adequate supply in terms of volume of credit required to bring about meaningful impact on the livelihood and poverty status of the rural women. Also, the dominance of religious group is an indication of the new role and potential impact that religious groups are likely to have on credit supply to rural women. This is indeed a pointer to the need for policies directed at economic empowerment of rural women to mainstream religious association into the strategies.

\section{Demand for Credit among Rural Women}

The average investment capital need of the rural women was estimated as N58,827.07 out of which $N 25,721$ representing (43.7\%) of the capital need was sought as credit from the micro-credit groups. However, the estimates showed that N23,707 or $(40.3 \%)$ of the credit requested for was financed by the group. This study revealed the high level of dependence of rural women on the micro-credit groups for investment capital and undoubtedly an indication of the significant role that the groups play in micro-credit financing. In addition, Table 3 shows that the investment capital 
Journal of Agricultural Extension

Vol. 12 (1) June, 2008

need of women farmers $(\$ 60,000)$ and consequently, the amount sought $(\$ 49,000)$ and obtained as micro-credit $(\$ 35,000)$ were significantly higher than those of women traders respectively $(P \leq 0.05)$. However, the amount obtained as credit by women farmers $(\mathrm{N} 35,000)$ was about $71 \%$ of the amount requested for compared to women traders who obtained about 99\% ( 22,138$)$ of their credit requisition as micro-credit.

Similarly, the results (Table 4) showed that the volume of credit requested and obtained from cooperative societies were significantly higher than those of local credit group. However, rural women rated local micro credit groups significantly higher $(P \leq 0.05)$ in terms of period of loan delivery and affordability of interest rates charged more than those of cooperative societies (Table 5).

TABLE 3: Credit Demand and Use of Credit among Rural Women

\begin{tabular}{|c|c|c|c|c|c|}
\hline & $\mathbf{N}$ & $\underset{\mathrm{m}}{\operatorname{Minimu}}$ & $\begin{array}{c}\text { Maximu } \\
\text { m }\end{array}$ & Mean & $\begin{array}{c}\text { Std. } \\
\text { Deviation }\end{array}$ \\
\hline Amount Required & 41 & 10000 & 70000 & $58,827.07$ & $16,694.89$ \\
\hline $\begin{array}{l}\text { Amount sought as } \\
\text { Credit }\end{array}$ & 41 & 10000 & 60000 & $25,721.71$ & $14,601.41$ \\
\hline Total Obtain as Credit & 41 & 9000 & 60000 & $23,707.31$ & $13,092.44$ \\
\hline \multicolumn{6}{|c|}{ Credit Demand by Purpose of Credit } \\
\hline & $\mathrm{N}$ & \multicolumn{2}{|c|}{ Need for Loan } & Mean & $\mathrm{t}$-Value \\
\hline \multirow[t]{2}{*}{ Amount Required } & 5 & \multicolumn{2}{|l|}{ Farming } & $0,000.00$ & \multirow[t]{2}{*}{$2.767^{*}$} \\
\hline & 36 & Trading & & $9,583.33$ & \\
\hline \multirow{2}{*}{$\begin{array}{l}\text { Amount sought as } \\
\text { Credit }\end{array}$} & 5 & \multicolumn{2}{|l|}{ Farming } & $9,000.00$ & \multirow[t]{2}{*}{$4.836^{*}$} \\
\hline & 36 & Trading & & $2,361.11$ & \\
\hline \multirow[t]{2}{*}{ Total Obtain as Credit } & 5 & Farming & & $5,000.00$ & \multirow[t]{2}{*}{$2.149^{*}$} \\
\hline & 36 & Trading & & $2,138.88$ & \\
\hline
\end{tabular}

Source: Survey data 2007

* Significant $(P \leq 0.05)$.

TABLE 4: Comparism of Credit Demand from Different Sources

\begin{tabular}{clcccc}
\hline Credit & \multicolumn{1}{c}{ Source1 } & N & Mean & Std. Deviation & $\begin{array}{c}\text { T- } \\
\text { Value }\end{array}$ \\
\hline Total sought & Cooperative & 6 & 40833.33 & 20836.67 & $3.084^{*}$ \\
& Local Credit Group & 35 & 23000.00 & 11517.25 & \\
Total granted & Cooperative & 6 & 35000.00 & 20736.44 & $2.422^{*}$ \\
& Local Credit Group & 35 & 21771.42 & 10586.02 & \\
\hline
\end{tabular}

Source: Survey data 2007

* Significant $(P \leq 0.05)$. 
TABLE 5: Relative Performance Score of Sources of Credit

\begin{tabular}{llccc}
\hline Performance Parameter & Credit Sources & N & Mean & T-Value \\
\hline Volume of Credit & Cooperative Society & 23 & 2.92 & $2.491^{*}$ \\
& Local Credit Group & 40 & 2.65 & \\
Period of Delivery & Cooperative Society & 23 & 2.30 & $4.763^{*}$ \\
& Local Credit Group & 40 & 2.83 & \\
Affordability of Interest Rate & Cooperative Society & 23 & 1.00 & $2.782^{*}$ \\
& Local Credit Group & 40 & 2.48 & \\
\hline
\end{tabular}

Source: Survey data 2007

* Significant $(\mathrm{P} \leq 0.05)$.

\section{Membership of Micro-Credit Group and Poverty Status of Rural Women}

It has been established that rather than being an end itself, provision of micro-credit is a tool to an end of alleviating poverty especially among rural dwellers. Hence, the yardstick for measuring the effectiveness of micro-credit groups is not limited to assessing its potential in provision of credit to its members but also to investigate whether such function has been translated to improvement in poverty status of the members. While assessment of credit delivery and recovery potential relates principally to the operational efficiency of the groups, the possibility of provided credit translating to improvement of poverty status of members relates to the use efficiency of such credit which is in turn affected by factors including the both the loanee-specific and enterprise-specific attributes.

The average monthly expenditure of the respondents was estimated as $\mathrm{N} 14,559.62$ and this was used in determining the poverty status into which each of the respondents belong as done by Oke et al (2007). The results presented in Table 6 showed that majority of members $(77.5 \%)$ and non members $(66.7 \%)$ were poor while the Chi-square value suggested that there was no significant relationship between membership of micro-credit group and poverty status of rural women. Hence; membership of micro-credit group had no significant relationship with the poverty status of rural women in the study area. This could probably be attributed to the dominance of non-formal credit institutions and its attendant problem of been able to guarantee meager amount as loan to its members. The study has earlier shown the estimate of average volume of credit as ranging from about $N 21,000$ to $\$ 35,000$ per year from both local credit group and cooperative societies respectively. 
Journal of Agricultural Extension

Vol. 12 (1) June, 2008

TABLE 6: Distribution of rural women by membership of micro-credit group and Poverty Status

\begin{tabular}{lcccccc}
\hline Poverty Status & \multicolumn{3}{c}{$\begin{array}{c}\text { Membership of Micro-credit } \\
\text { Group }\end{array}$} & \multicolumn{2}{c}{ Chi Square Value } \\
\cline { 2 - 5 } & \multicolumn{3}{c}{ Member } & Non Member & Value & Remark \\
\cline { 2 - 5 } & Freq & $\%$ & Freq & $\%$ & & \\
\cline { 2 - 5 } Poor & 69 & 77.5 & 10 & 66.7 & 0.829 & NS \\
Non Poor & 20 & 22.5 & 05 & 33.3 & & \\
Total & 89 & 100.0 & 15 & 100.0 & & \\
\hline
\end{tabular}

Source: Survey data 2007

$N S=$ Not Significant $(P \leq 0.05)$

In addition, the average monthly expenditure profile of rural women members and non members of micro credit group (Table 7) showed that food accounted for the greatest percentage of expensed incurred personally by women in the households. However, there was no significant difference in the expenditure profile of rural women who were members of micro credit groups and non members thereby underscoring the earlier suggestion that participation in micro-credit group was yet to have any significant member in the poverty status of rural women.

TABLE 7: Comparism of Average Expenditure by Membership of Association

\begin{tabular}{|l|l|l|l|l|l|}
\hline \multirow{2}{*}{ Expenditure } & \multicolumn{2}{|c|}{$\begin{array}{c}\text { Membership of Micro- } \\
\text { credit Group }\end{array}$} & \multicolumn{3}{c|}{ T-statistics } \\
\cline { 2 - 6 } & Member & Non Member & Value & P Level & Remark \\
\hline Food & $12,280.90$ & $10,226.67$ & 1.17 & 0.24 & NS \\
\hline Cloth & 876.40 & 493.33 & 1.86 & 0.07 & NS \\
\hline Household Utensils & 260.67 & 220.00 & .1 .45 & 0.15 & NS \\
\hline $\begin{array}{l}\text { Children's } \\
\text { education }\end{array}$ & 780.89 & 440.01 & 1.70 & 0.09 & NS \\
\hline Family Health & 349.44 & 293.33 & 1.67 & 0.09 & NS \\
\hline Social Functions & 430.34 & 360.00 & 1.36 & 0.17 & NS \\
\hline Total Expenditure & $14,978.65$ & $12,073.33$ & 1.47 & 0.15 & NS \\
\hline
\end{tabular}

Source: Survey data 2007

NS= Not Significant $(P \leq 0.05)$

\section{Constraints in Sourcing of credit from micro credit groups}

Table 8 showed the relative importance of constraints faced by rural women in sourcing micro-credit. The distribution shows that inability to get information on sources of credit, difficulty in coping with the required protocols, problem of finding suitable guarantor are the prominent constraints against sourcing finance from microcredit institutions. It is however evident that the bulk of this constraints are more relevant to credit sourcing from formal micro-credit institutions rather than the non formal sectors. 
Table 8: Constants in Sourcing of Micro-credit by Rural Women

\begin{tabular}{|l|c|c|}
\hline \multicolumn{1}{|c|}{ Constraint } & $\begin{array}{c}\text { No of } \\
\text { Respondents }\end{array}$ & Percentage \\
\hline Lack of Information on Sources & 104 & 100.0 \\
Difficulty in Coping with Protocols & 68 & 65.4 \\
Issue of collateral & 48 & 46.2 \\
Finding Guarantor & 65 & 62.5 \\
High Interest Rate & 29 & 27.9 \\
Untimely Delivery & 21 & 20.2 \\
Distance to Credit Institutions & 21 & 20.2 \\
\hline
\end{tabular}

Source: Survey data 2007

\section{CONCLUSION}

The results obtained from this study have shown that non-formal micro credit institutions form the most prominent sources of micro-credit to rural women. Specifically, local micro credit groups including traders and religious associations represented the dominant sources of micro credit through which they were able to source about $80 \%$ of the capital need as credit. The study also showed that more credit was demanded for investment in farming than trading with cooperative societies granting higher volume of credit. However, the performance of local credit group was rated higher by the rural women in terms of promptness of credit delivery and affordability of rates charged. However, the study showed that membership of microcredit did not have any significant relationship with the poverty status of the women. The study however suggested that policy efforts directed at giving publicity to the operations of formal micro-finance institutions through training programmes and awareness campaign could go a long way in removing some of the bottlenecks already experienced by rural women and thus enhanced their patronage of formal institutions for improved credit delivery and standard of living. Similarly, better appreciation needs to be accorded the role that is now been played by religious association in mobilizing rural women for enhanced access to micro credit.

The religious associations are likely to have structures that are easily amenable to organized reforms that could help increased access to greater volume of credit from formal sources like government credit agencies, micro-finance banks and commercial banks. 
Journal of Agricultural Extension

Vol. 12 (1) June, 2008

\section{References}

Ajao, A. O. (2000). Production Risk and Resource -Use Effciciency Among the Participants of the Women in Agriculture Programme of the Oyo State Agricultural Development Project. Unpublished M.Sc. Thesis. Obafemi Awolowo University lle-Ife, 80p

Ajani O. I. Y. (2008) Gender Dimensions in Agriculture, Poverty, Nutrition and Food Security in Nigeria. International Food Policy Research Institute (IFPRI)

http://www.ifpri.org/events/seminars/2008/20080520/20080520Ajani.pdf

Ajetomobi, J. O. (1995). Economic Efficiency of Women Farmers within the Ondo State Agricultural Development Programme. Unpublished M.Sc. Thesis. Obafemi Awolowo University lle-Ife, 156p.

Ayanwale A. B. and Alimi T (2004) Microfinancing as a Poverty Alleviation Measure: A Gender Analysis. J. Soc. Sci., 9(2): 111-117 (2004)

C.B.N (1999), "Poverty Alleviation in Nigeria (1999)", Bulletin Vol. 23, No. 4 Oct./Dec.

CBN (2005) Microfinance policy, Regulatory and Supervisory Framework for Nigeria.

http://www.cenbank.org/out/publications/guidelines/dfd/2006/microfinance $\% 20 p$ olicy.pdf

Central Intelligence Agency (2008) CIA World Fact Book: Nigeria.

https://www.cia.gov/library/publications/the-world-factbook/geos/ni.html (last accessed September 10th, 2004)

DFID (2008) Country Profile:Nigeria.

http://www.dfid.gov.uk/countries/africa/nigeria.asp (last accessed September $\left.10^{\text {th }}, 2008\right)$

Federal Office of Statistics. (1999). Poverty Profile for Nigeria 1980-1996. Lagos: Federal Office of Statistics.

Kareem R. O., Dipeolu A. O., Aromolaran A. B. and S. B. Williams (2008) Economic efficiency in fish farming: hope for agro-allied industries in Nigeria. Chinese Journal of Oceanology and Limnology Vol. 26 No. 1, P. 104-115

Kessey C. (2005) Empowering Muslim Women Through Microcredit Scheme: The Case of the Sunyani Gonja Muslim Women's Group. W O P A G - Working Papers on Ghana: Historical and Contemporary Studies Nr 7. Pg. 20.

Nwachukwu I. N., Ezeh C. I. and I. Nwachukwu (2007) Impact of some Selected Rural Development Programmes on Poverty Alleviation in Ikwuano LGA of Abia State, Nigeria. African Journal of Food Agriculture, Nutrition and Development. Vol. 7. Nos.5. http://www.ajfand.net/Issue16/PDFs/Nwachukwu 2245.pdf

Ogwumike F.O (2002) "An Appraisal of Poverty Reduction Strategies in Nigeria" CBN Economic and Financial Review, Vol.37 No.4.

Oke J T. O., R. Adeyemo and M.U. Agbonlahor (2007) An Empirical Analysis of Microcredit Repayment in Southwestern Nigeria. Humanity \& Social Sciences Journal 2 (1): 63-74.

Okoruwa, V O and O.A Oni (2002) "Agricultural Inputs and farmers' Welfare in Nigeria" In Poverty Reduction and the Nigeria Agricultural Sector. F Okunmadewa (ed.), Published by Elshaddai Global Ventures Ltd, Ibadan. 
Okunmadewa, F .Y (2001) "Poverty Reduction in Nigeria: A Four-Point Demand". An Annual Lecture of the House, University of Ibadan. Ibadan.

UNDP (1998). Nigerian Human Development Report 1998. Lagos: United Nations Development Programme.

U. N. O. (1998) Role of micro credit in the eradication of poverty. Report of the Secretary-General on Implementation of the First United Nations Decade for the Eradication of Poverty (1997-2006). United Nations General Assembly. A/53/223.

World Bank (2000/2001); World Development Report "Attacking Poverty".

World Bank. 1999. World Development Report 2000/2001 Consultation with the Poor. Nigeria: Voice of the Poor. Country Synthesis Report Nigeria. 